\title{
Central bank independence and economic performance in eastern Europe
}

\author{
Bilin Neyapti* \\ Bilkent University, 06533 Bilkent, Ankara, Turkey
}

Accepted 8 November 2001

\begin{abstract}
Following the breakdown of central planning by the early 1990s, transition economies faced varying measures of the need for economic restructuring and stabilisation. This paper examines both the trends in economic performance in eight eastern European countries and the degree of central bank independence (CBI) granted after reforms. The evidence of the paper indicates that both the measures of CBI and the measures of financial market development (FMD) show significant association with macroeconomic variables. Also, the sample exhibits positive association between CBI and measures of FMD. (c) 2001 Elsevier Science B.V. All rights reserved.
\end{abstract}

JEL classification: E58; P27; P34

Keywords: Central bank independence; Financial market development; Eastern Europe; Transition; Inflation

\section{Introduction}

Since 1989, the former centrally-planned economies have launched political and economic reforms that included varying degrees of stabilisation, liberalisation, restructuring and privatisation. In countries where decades of central planning prevented the development of market forces and institutional mechanisms for efficient resource allocation, transition to a market economy required substantial institution building. By investigating both the status of central banking reforms and their role in economic performance, this paper focuses on one such aspect of institution building.

A common feature of financial sector reforms in transition economies was replacing the monobank system with a two-tier system that legally separated savings and commercial banks from the central bank (CB). ${ }^{1}$ Savings and commercial banks thus emerged out of the

\footnotetext{
* Tel.: +90-312-290-2030; fax: +90-312-266-5140.

E-mail address: neyapti@bilkent.edu.tr (B. Neyapti).

${ }^{1}$ Thorne (1993) provides a detailed account of bank reforms in Hungary, Poland, CSFR, Bulgaria and Romania.
} 
former branches of the $\mathrm{CB}$ and took over the management of saving and credit transactions with the household and enterprise sectors. The persisting linkages within the financial system and those between the financial system and the enterprise sector, on the one hand, and both of their linkages with the government, on the other, posed impediments for rapid success in stabilising transition economies to varying extents. ${ }^{2}$

In addition to the weak financial system, concentrated industrial structures and large state-owned enterprises of the central planning period enhanced the capacity of enterprises to organise as special-interest lobbying groups. During transition, these enterprises opposed market reforms since they desired to maintain the flow of resources that they were accustomed to obtain, regardless of the degree of their efficiency. ${ }^{3}$ Moreover, a sizeable portion of the banking sector that remained state- or enterprise-owned continued to lend to inefficient enterprises.

Local governments also posed an additional source of resistance to bank and enterprise structuring. As fiscal decentralisation of the former socialist states led local governments to assume many social spending functions at the local level, the central government maintained much of the tax collection function. Local governments therefore resisted the privatisation of local enterprises that remained to be their main source of revenue.

Furthermore, in the absence of prudent regulatory and supervisory mechanisms, managers of banks and enterprises that are subject to restructuring often appropriated the profits and assets. Recapitalising such banks and enterprises necessitated large amounts of funds. Given the implied social or political costs of restructuring enterprises that are "too big to fail", fiscal and monetary authorities in many transition economies continued to subsidise them. Thus, the continued flow of funds to inefficient enterprises generated substantial pressure for inflationary monetary expansion in many transition economies.

Inherited economic distortions generated further challenge to stabilisation and market reforms in transition economies. As the inherited monetary overhang and shortages led to high rates of inflation in the periods that followed price liberalisation, expectations of a reform failure and uncertainty about the new relative price structures led enterprises to initially set prices above the market-clearing levels in order to obtain short-term gains. Moreover, as state control over the economy subsided, tax revenues declined, ${ }^{4}$ increasing the fiscal deficits and thus pressures for inflationary credit expansion. At the onset of market reforms, most transition economies lacked the institutional mechanisms that were necessary to eliminate inflationary pressures, such as a developed financial sector and a sophisticated tax collection system. The absence of both fiscal and financial discipline aggravated these difficulties in implementing market reforms.

This paper argues that both central bank independence (CBI) and financial market development (FMD) may facilitate market reforms by helping to enforce fiscal and financial discipline. CBI is generally considered a mechanism to separate monetary policy from

\footnotetext{
${ }^{2}$ During central planning, the central bank provided funds to enterprises, not according to enterprise efficiency, but according to a central plan. As a result, banks lacked incentives to avoid risk and thus a large portion of a bank portfolio typically consisted of non-performing or low-quality enterprise loans, generating a great source of pressure on central bank financing.

${ }^{3}$ See Olson (1995) for the case of the former Soviet Union.

${ }^{4}$ McKinnon (1992) gives examples to this phenomenon from the USSR and China. The same phenomenon can also be observed in other transition economies, such as Poland, Hungary and Romania.
} 
short-term fiscal pressures; it thus symbolises the commitment of political authorities to price stability (Barro and Gordon, 1983; Cukierman and Meltzer, 1989; Cukierman, 1992). In addition, several studies, including Grilli et al. (1991), Alesina and Summers (1993) and Cukierman, Webb, Neypati (1992) and Cukierman, Miller, Neypati (2001, in press), show the negative association of CBI with the level and variability of inflation. In view of the increase in the number of legally independent CBs in the 1990s, Maxfield (1994, 1997) studies the underlying motives and circumstances for creating an independent $C B$ in developing countries. Among those motives, she emphasises the motive of signalling creditworthiness.

Policy makers who are strongly committed to establishing financial discipline and price stability may grant CBI. Maintaining CBI, however, requires, inter alia, politically powerful groups that have anti-inflationary incentives. As Goodman (1991) and Posen (1994) point out, FMD is most likely to yield such strong anti-inflationary interest groups. A developed financial market not only provides the government with non-inflationary means to finance fiscal deficits and is, therefore, usually associated with low inflation, but it is also likely to generate a strong opposition to inflation, because inflation harms financial intermediaries that lend long term and borrow short term. Hence, as a developed financial market facilitates both establishing and maintaining an independent $\mathrm{CB}, \mathrm{CBI}$, in turn, facilitates FMD by forcing, through hard budget constraints, financial intermediaries to lend efficiently.

Economies with high inflation and deficits may, nevertheless, have difficulty in adopting laws and regulations to attain an independent $\mathrm{CB}$ and a developed financial system as the government's financing needs and the formation of inflation lobbies usually hinder such developments. Hence, causality between such institutional measures and macroeconomic indicators can in fact be both ways.

This paper explores the association of both CBI and FMD with the economic performance of eight former centrally-planned eastern European countries in transition, namely, Albania, Bulgaria, the Czech Republic, Slovak Republic, Hungary, Poland, Romania and Slovenia. The measure of the degree of CBI is based on the set of criteria developed by Cukierman et al. (1992, referred to as CWN herein). This measurement reveals that many transition economies in eastern Europe have adopted laws that grant the $\mathrm{CB}$ rather high degrees of independence, even when compared to the Bundesbank which is considered to be the most independent CB. We then modify this set of criteria by adding three other criteria: (1) financial independence of the CB, (2) supervision of banks, and (3) emergency credits, the latter of which is particularly relevant for transition economies, where, due to a weak financial system, the $\mathrm{CB}$ is more likely to be viewed as the lender of last resort than otherwise.

Next, we provide several measures of FMD: the ratio of credit to the private sector to GDP, the M2 to GDP ratio (also called as financial deepening), the interest spread (lending deposit rate), the ratio of time deposits to GDP (as a measure of confidence in the banking sector $^{5}$ ) and, the real interest rates.

Finally, we investigate the association of these CBI and FMD indices with some major macroeconomic indicators. The findings of this analysis suggest that both the degree of CBI

\footnotetext{
${ }^{5}$ Clague et al. (1995) use the ratio of the non-currency component of M2, which they call as "contract-intensive money", as a measure of institutional development and observe that this indicator is positively associated with the level of financial market development.
} 
Table 1

Dates of major reforms in eastern Europe ${ }^{\mathrm{a}}$

\begin{tabular}{|c|c|c|c|c|c|}
\hline & $\begin{array}{l}\text { Latest central } \\
\text { bank law }\end{array}$ & $\begin{array}{l}\text { Economic } \\
\text { reforms }\end{array}$ & $\begin{array}{l}\text { Breakdown of } \\
\text { the monobank }\end{array}$ & $\begin{array}{l}\text { Political reforms/ } \\
\text { independence }\end{array}$ & $\begin{array}{l}\text { First free } \\
\text { elections }\end{array}$ \\
\hline Albania & April 1992 & August 1992 & August 1992 & December 1990 & March 1991 \\
\hline Bulgaria & June 1991 & February 1991 & March 1990 & November 1989 & June 1990 \\
\hline $\begin{array}{l}\text { Czech } \\
\text { Republic }\end{array}$ & December 1991 & January 1991 & January 1990 & November 1989 & June 1990 \\
\hline Hungary & October 1991 & January 1991 & January 1987 & October 1989 & April 1990 \\
\hline Poland & October 1991 & January 1990 & February 1989 & April 1989 & December 1990 \\
\hline Romania & January 1991 & April 1991 & December 1990 & December 1989 & May 1990 \\
\hline $\begin{array}{l}\text { Slovak } \\
\quad \text { Republic }\end{array}$ & November 1992 & January 1991 & January 1990 & December 1992 & June 1990 \\
\hline Slovenia & October 1991 & October 1991 & 1958 & June 1991 & April 1990 \\
\hline
\end{tabular}

${ }^{a}$ Source: Keesings, various issues.

and the measures of FMD appear to be related with selected macroeconomic variables of interest.

\section{Measurement of central bank independence}

In this section, we investigate the recent CB laws of Albania, Bulgaria, the Czech Republic and Slovak Republic, Hungary, Poland, Romania and Slovenia, which were all enacted in the early 1990s. Table 1 reports the dates of these reforms, as well as the dates of other important economic and political reforms in these countries.

To measure the degree of CBI, we employ the comprehensive list of criteria developed by CWN. CWN measure the degree of legal CBI based on 16 criteria constructed from CB charters. They summarise these criteria in four main groups: (i) the chief executive officer (CEO) (appointment, dismissal, term of office and freedom to hold a position in the government sector), (ii) the main objective of the $\mathrm{CB}$, (iii) policy formulations - the role of the $\mathrm{CB}$ in formulating monetary policy and affecting government budget decisions - and, (iv) limitations on lending - the terms of lending and the role of the CB in the determination of these terms. Appendix A lists these criteria in detail and reports the decision rules for coding. ${ }^{6}$

As demonstrated in Appendix B, the CBs of the Czech Republic, Hungary, Poland and Slovenia have the highest degree of independence in terms of legal provisions for the CEO. These countries also have the lowest rates of inflation in the period immediately following the enactment of the recent $\mathrm{CB}$ laws. In addition, according to the list of criteria classified as policy formulations, the Czech Republic, Hungary and the Slovak Republic, followed by Poland, rank the highest. By contrast, Romania has the lowest degree of CBI with respect to the CEO, the objectives of the CB and the limitations on lending. This observation is consistent with Romania also having the highest rate of inflation, along with Bulgaria, during the 3 years following the enactment of the recent $C B$ laws.

\footnotetext{
${ }^{6}$ Due to the mostly qualitative nature of the set of criteria to measure CBI, the numerical codings may contain some degree of subjectivity. We nevertheless try to minimize this problem by using a detailed set of decision rules to code each criterion.
} 
Table 2

Indices of legal $\mathrm{CBI}^{\mathrm{a}}$ based on $\mathrm{CWN}$ criteria

\begin{tabular}{lllllllll}
\hline & Albania & Bulgaria & $\begin{array}{l}\text { Czech } \\
\text { Republic }\end{array}$ & Hungary & Poland & Romania & $\begin{array}{l}\text { Slovak } \\
\text { Republic }\end{array}$ & Slovenia \\
\hline Legal CBI & 0.34 & 0.49 & 0.62 & 0.63 & 0.36 & 0.26 & 0.42 & 0.56 \\
Rank & 7 & 4 & 2 & 1 & 6 & 8 & 5 & 3 \\
\hline
\end{tabular}

${ }^{a}$ Normalised to between 0 and 1, increasing numbers indicate more independence.

With respect to legal limitations on lending, Bulgaria, Albania and the Slovak Republic are placed at the top of the sample, while Poland and Romania are ranked at the bottom. The fact that both Albania and Bulgaria have had some of the highest budget deficits and output declines in the sample, however, brings into question the feasibility of enforcing the legal limitations on lending in these countries.

Table 2 reports the aggregate indices of legal CBI based on these four groups or the 16 criteria documented in Appendix A. According to these indices, all countries in the sample, with the exception of Romania, have adopted CB laws that indicate relatively high degrees of independence. In fact, five out of the eight countries have a higher than the mean level (0.36) of legal CBI in the developed countries sample used in CWN. In addition, the legal CBI indices for Bulgaria, the Czech Republic, Hungary and Slovenia match the top $25 \%$ ranking for the developed countries reported in the CWN for the 1980s.

In this paper, we modify CWN's criteria for legal CBI by including three additional criteria, based on Neyapti (1997). We report below those criteria along with the decision rules for their coding. In addition, Appendix B lists the modified measurement criteria, along with the numerical codings of the sample countries.

\section{Additional criteria to measure CBI}

Financial independence (determination of the budget of the $\mathrm{CB}$ and salaries of high-ranking bank officials)

Mostly the CB

Mostly the CB or fixed by law

Mixture of the $\mathrm{CB}$, executive and legislative

Mostly the executive and legislative

\section{Supervisory role}

Detailed rules and regulations by the $\mathrm{CB}$ on credit extended by the banks, close monitoring on compliance and penalty enforcement

The CB is involved in close monitoring, such as in case of decisions on bank reorganisation

The $\mathrm{CB}$ has the right to examine and demand periodical auditing

No clear statement on supervisory functions

\section{Emergency credit}

There is no provision on emergency credit to the banks

There exists a provision on the possibility of emergency credit with no strict limits

Note that the increasing numbers indicate decreasing independence. 
The criterion of financial independence codifies the role of the government in determining both the budget and salaries of the higher-ranking staff of the CB. With these criteria, we intend to measure the government's influence on the decision making of $\mathrm{CB}$ officers. ${ }^{7}$

We hypothesise that good banking regulation and supervision facilitate the enforcement of hard budget constraints and thus enforce fiscal and financial discipline, which in turn helps to sustain CBI. Although, we do not necessarily advocate the view that the $\mathrm{CB}$ should supervise the banking system, CBs usually do perform this function. ${ }^{8}$ (In our sample of eight eastern European countries, the exception to this is Hungary, where the Banking Supervisory Committee, which consists of the representatives of the $\mathrm{CB}$, the government and the banking system, is responsible for bank supervision.) We therefore evaluate the quality of bank supervision based on the stipulations in $\mathrm{CB}$ laws.

Co-ordinating bank supervision with the CBs' role as both the guarantor of the payments system and as the lender of the last resort is one of the arguments for vesting bank supervision with an independent CB. If, however, a CB rescues problem banks to avoid contagion effects, it may secure long-term financial stability, but possibly damage its credibility, since such bank rescues usually require monetary expansion, which conflicts with the goal of price stability. On the other hand, a strict regulator that permits bank failures that, in turn, lead to systemic failures may, in effect, require a wider-scale CB rescue. Goodhart (1995), Roe (1992), Heller (1991) and Sundararajan (1990) all discuss the advantages and disadvantages of the CB's performing the function of bank supervision. This paper takes the view that clear mandates about the CB's role in bank supervision can facilitate the implementation of hard budget constraints.

We also include the terms of emergency credits to banks in the list of criteria to measure CBI. Transition economies are especially prone to banks becoming illiquid or insolvent, which often threatens the stability of the whole system. Thus, in addition to strong bank supervision and regulation to reduce the risk of financial failures, limiting the CB's emergency lending to banks would help to enforce the credibility of hard budget constraints. This could help create financial discipline, which, in turn, would help maintain the independence of the CB.

Table 3 reports the legal CBI indices based on this modified set of criteria, which combines the 16 criteria of CWN with the above three. In addition, it provides the ranks of countries based on these indices.

\footnotetext{
${ }^{7} \mathrm{CWN}$ use this criteria to form the questionnaire-based indices of $\mathrm{CBI}$, to proxy the degree of independence in practice. In this study, we incorporate this criterion to modify the measurement of CBI based on central bank laws.

${ }^{8}$ Although there is no clear evidence to suggest that the central bank is better in bank supervision than other supervisory agencies, according to a survey by Goodhart (1995), in half of the 22 developed countries central banks are in charge of bank supervision. In addition, Goodhart reports that, of the 104 cases of bank failures in 24 (mostly developed) countries since the 1980 s, in only 33 cases did the central bank have a supervisory function. In the majority of the remaining cases, the supervisory function was performed by the government. There were 27 cases where the central bank was the only source of funding for the failing banks, but only in six of those cases did the central bank hold the supervisory function. Thus, he concludes that there is no clear case for or against the separation of the supervisory function from the monetary authority.
} 
Table 3

Modified indices of legal CBI ${ }^{\mathrm{a}}$

\begin{tabular}{lllllllll}
\hline & Albania & Bulgaria & $\begin{array}{l}\text { Czech } \\
\text { Republic }\end{array}$ & Hungary & Poland & Romania & $\begin{array}{l}\text { Slovak } \\
\text { Republic }\end{array}$ & Slovenia \\
\hline Legal CBI & 0.35 & 0.54 & 0.64 & 0.6 & 0.44 & 0.31 & na & 0.71 \\
Rank & 6 & 4 & 2 & 3 & 5 & 7 & na & 1 \\
\hline
\end{tabular}

${ }^{\text {a }}$ Normalised to between 0 and 1, increasing numbers indicate more independence.

\subsection{Compliance with central bank law}

To measure the degree of compliance with CB laws, we compare the legal lending limits with the actual lending practices of the CBs. We note that an independent $\mathrm{CB}$ may be a mere formal institutional arrangement and may, in some economies, be largely associated with lack of compliance. To measure such deviation from the intent of the law, Table 4 compares the legal limits on CB lending to the government with the figures in practice.

CWN argue that limiting the CB's lending to the government in terms of the shares of government revenues implies a relatively higher degree of CBI than limiting it in terms of government expenditures, since the latter implies relatively more government discretion (see decision rules for the coding criteria in Appendix A). Accordingly, in the most recent CB laws of Bulgaria, the Czech Republic, Slovak Republic and Hungary, the limitations on $\mathrm{CB}$ lending to the government are defined as up to $5 \%$ of the government revenues (based on the expected or the past levels, depending on the country). Although the limits of lending for Poland and Slovenia are defined in terms of government expenditures, the limits are also quite strict ( 2 and $5 \%$, respectively). By contrast, the limits on CB lending to the government appear much looser in Romania and Albania than in the rest of the sample.

Table 4

Comparisons between actual lending and the legal limits ${ }^{\mathrm{a}}$

\begin{tabular}{|c|c|c|c|c|c|c|}
\hline & \multirow[t]{2}{*}{$\begin{array}{l}\text { Legal lending limits on central } \\
\text { bank credit to the government }\end{array}$} & \multicolumn{5}{|c|}{$\begin{array}{l}\text { Actual central bank credit } \\
\text { (percentage of the basis of the legal limits) }^{b}\end{array}$} \\
\hline & & 1991 & 1992 & 1993 & 1994 & 1995 \\
\hline Albania & $10 \%$ of past government revenue & & & & & \\
\hline Bulgaria & $5 \%$ of expected govt. revenue & & & & & \\
\hline Czech Republic & $5 \%$ of past government revenue & & - & - & -11.5 & -5.7 \\
\hline Hungary & $3 \%$ of expected govt. revenue & & 6.7 & 1.6 & 5.7 & -2.4 \\
\hline Poland & $2 \%$ of expected govt. expenditure & & 13.1 & 4.6 & 3.6 & -5.6 \\
\hline Romania & $10 \%$ of expected govt expenditure & 4.4 & 8.8 & 1.1 & 8.5 & 7.2 \\
\hline Slovak Republic & $5 \%$ of past government revenue & & & - & 0.0 & -9.0 \\
\hline Slovenia & $\begin{array}{l}5 \% \text { of expected government } \\
\text { expenditure (or } 20 \% \text { of deficit) }\end{array}$ & & 0.1 & 1.5 & -0.4 & 0 \\
\hline
\end{tabular}

\footnotetext{
a Sources: central bank and statistical bulletins, IMF, international financial statistics and MultiQuery database, The World Bank, Europe and central Asia region, 1996.

${ }^{\mathrm{b}}$ Start year: last CB laws; 1995: preliminary.
} 
Among the countries for which data is available, the Slovak Republic, Slovenia and Romania were within the limits of lending that are stipulated in the respective CB charters. Hungary, Poland and the Czech Republic have joined this group in 1995. Although the CB of Romania did not violate the legal limits of lending, the amount of lending was, except for 1993, relatively high. In Poland, there has been a substantial decline in CB lending to the government since 1993.

We note, however, that data on budget deficits and credit possibly contain errors due to various measurement problems pertaining to transition. In addition, data coverage is mostly limited to central governments, except for Poland and Romania where data on the general government is available. The lack of consistent measurement of the sizeable quasi-fiscal deficits poses important problems for empirical analyses. Moreover, data on credit is lacking for Albania and Bulgaria. This analysis, therefore, is only a preliminary attempt to measure the compliance with CB laws and can be improved as more and better quality data becomes available.

\subsection{Other measurements of central bank independence for transition economies}

Siklos (1993) employs CWN's method of measuring CBI in a study that covers half of this study's sample, namely Poland, Hungary and the Czech and Slovak Republics. His analysis, however, differ from ours not only in sample coverage, but also in its approach and findings. ${ }^{9}$ In addition, the codings of the legal CBI in Siklos do not entirely match our codings, not only because he uses only a subset of the measurement criteria of CWN, but also because his interpretation of the law differs from ours with respect to some of the codings. Moreover, Siklos uses the actual and legal measures of CBI together by incorporating a set of economic conditions in the set of criteria to measure CBI. ${ }^{10}$ His codings give Czech and Polish CBs the highest ranking, Hungary the second and the Slovak Republic the lowest.

Loungani and Sheets (1997) examine the relationship between CB and inflation in 12 formerly socialist economies. Based on Debelle and Fischer (1994) approach, the authors measure CBI by an aggregation of goal independence and economic independence of the $\mathrm{CB}$ in 12 transition economies, 6 of which are the eastern and central European countries in our sample. According to this measure, the degree of CBI in Bulgaria and the Czech Republic matches with that of Germany. Among the countries that overlap with our sample, their ranking assigns the lowest independence to Hungary, and deviates largely form our ranking reported in Tables 2 and 3. ${ }^{11}$

\footnotetext{
${ }^{9}$ Using monthly data, Siklos estimates the reaction function for the central banks of Hungary and Poland and measures CBI both by the countercyclicality of money growth and interest rates and by the insensitiveness of these variables to political instability (proxied by elections and government change). He suggests that the Hungarian central bank is more independent than the Polish one, though using different time periods and lag structures for the two countries.

${ }^{10}$ Legal degree of CBI can also be a product of prevailing economic circumstances. However, causality can run both ways. CWN also address this question by providing measures of actual CBI: questionnaire-based indices and turnover rates of central bank governors.

${ }^{11}$ Loungani and Sheets' (1997) CBI codes for the countries that overlap with our sample are as follows: Albania: 0.75, Bulgaria: 0.875; Czech Republic: 0.875; Hungary: 0.312; Poland: 0.5 and Romania: 0.5.
} 
Table 5

Measures of FMD

\begin{tabular}{lcclccccc}
\hline & Albania & Bulgaria & $\begin{array}{l}\text { Czech } \\
\text { Republic }\end{array}$ & Hungary & Poland & Romania & $\begin{array}{l}\text { Slovak } \\
\text { Republic }\end{array}$ & Slovenia \\
\hline CRprvt & $3.8 \%$ & $4.4 \%$ & $28.9 \%$ & - & $11 \%$ & - & $28 \%$ & $23 \%$ \\
M2GDP & $40 \%$ & $62 \%$ & $67 \%$ & $45 \%$ & $31 \%$ & $18 \%$ & $69 \%$ & $24 \%$ \\
l-d & 5.9 & 32 & 6.7 & 8.6 & 7.3 & 25.8 & 5.7 & 15.5 \\
TDGDP & $11 \%$ & - & $45 \%$ & $25 \%$ & $24 \%$ & $12 \%$ & $39 \%$ & $28 \%$ \\
Rint & -14 & 0.97 & -4.9 & 6.5 & 2.5 & - & -0.1 & 5.8 \\
\hline
\end{tabular}

${ }^{a}$ The definitions are given in Section 3. Data is in averages over the 3 years following the enactment of the most recent central bank laws, where available. Data are obtained from European Bank for Reconstruction and Development, 1999, Transition Update; and Global Development Finance and World Development Indicators of the World Bank.

\section{The relationship between CB independence, financial market development and macroeconomic performance}

This section explores the association of both the modified index of CBI and the indices of FMD with four macroeconomic indicators: inflation, the ratio of budget deficits to GDP and the growth rate of real output. We use several indicators to measure FMD: M2:GDP ratio (M2GDP), the ratio of credit to the private sector to GDP (CRprvt), the spread between lending and deposit interests (l-d), real interest rates, and the ratio of time deposits (including savings and foreign deposits) to GDP (TDGDP). The first of these measures is a measure of financial deepening. The last variable (TDGDP) is also called quasi-money, which, due to its non-liquid nature, is considered to reflect confidence in the financial system. ${ }^{12}$ Since none of these indicators is, by itself, a perfect measure of FMD, we employ all of them in our tests. Table 5 reports all these indicators for the years that follow the enactment of the CB laws in the sample countries, when available.

We note that the correlations between both financial deepening (M2GDP) and CBI and TDGDP and CBI are positive and significant at the 5\% level. Though the rest of the FMD measures are also correlated with CBI with the expected signs, they are not statistically significant at conventional levels. In the empirical analysis below, we test the hypotheses that both CBI and FMD are negatively correlated with inflation and deficits, and positively correlated with real growth.

\subsection{Some observations}

Data on the macroeconomic variables ${ }^{13}$ reveal that the majority of the countries in the sample had their highest rate of output declines in 1991, ranging from as high as $28 \%$ in Albania to $7 \%$ in Hungary. Gradual implementation of market reforms in that country since the 1970s can explain the relatively low peak output decline in Hungary. The peak levels of output decline in the Slovak Republic and Poland occurred in 1989 and 1990, by 50\%

\footnotetext{
12 See Clague et al. (1995). Here, quasi-money includes foreign deposits.

${ }^{13}$ Data is obtained from European Bank for Reconstruction and Development, 1999, Transition Update. Data on some of the FMD measures, namely CRprvt and rint, are obtained from World Bank reports.
} 
and $12 \%$, respectively. Three of the eight countries in our sample also experienced their highest inflation rates in 1991: the Czech Republic and Slovak Republic with 57\% and $61 \%$, respectively, Hungary with $35 \%$. Five of the eight countries in the sample reduced their average annual inflation rates to below $15 \%$ by 1998 . Since 1997, after the adoption of the new CB laws, Bulgaria, in the aftermath of the extensive banking crisis, and Romania experienced the highest rate of inflation in the sample.

During the period from 1994 to 1996, Albania, Poland and the Slovak Republic all recorded significant rates of real GDP growth - more than 5\% on average, on an annual basis. The rest of the countries in the sample, with the exception of Bulgaria, also showed varying degrees of recovery after the reforms. ${ }^{14}$ In 1997, however, Albania, Bulgaria and Romania all experienced significant output losses, partly attributable to the prevalent financial crises.

By 1996, five of the countries in the sample managed to reduce their budget deficits to below 5\% of GDP. By contrast, Albania and Bulgaria experienced persistent high budget deficits since the reforms, though a recovery is observed in Bulgaria since 1997. Slovenia and the Czech Republic have experienced relatively better budgetary performances than the rest of the countries. In addition, unemployment continues to be a significant problem in almost all countries in the sample, in which the Czech Republic ranks lowest with $7.5 \%$ in 1998.

In most of the sample countries, the decline in inflation coincides with the introduction of new CB laws, most of which implied relatively high degrees of independence. Only in Bulgaria and Romania, however, inflation reached triple digits after the enactment of its most recent CB law. Of these, it is interesting to note that the $\mathrm{CB}$ of Romania has the lowest degree of independence of all the countries in the sample (Table 3).

These observations may suggest a positive association between CBI and price stability. The causality between CBI and price stability, however, can go both ways. On the one hand, an independent CB may help to achieve price stability by implementing hard budget constraints and by pursuing policies geared to long-term financial stability; on the other hand, serious reformers who secure social and political support for market reforms, and also face favourable initial economic conditions, may be more likely to adopt laws that grant the CBI.

Indeed, the relatively favourable initial conditions - such as the lower external debt of the Czech Republic and Slovak Republic, the weaker enterprise associations in Hungary and the Czech Republic, the partially liberalised price structure and partial commercialisation in Hungary, as well as in Poland, have possibly all contributed to these countries' relatively better economic performances after the initiation of market reforms. ${ }^{15}$ By 1994, GDP shares of the private sector in the Czech Republic, Slovak Republic, Poland and Hungary reached 56, 58, 52 and 60\%, respectively. By contrast, Bulgaria and Romania still had relatively small private sector shares in GDP, 21.8 and 35\%, respectively (no data are available for Albania and Slovenia). The higher share of the private sector in the Czech Republic, Slovak

\footnotetext{
${ }^{14}$ Difficulties, however, exist in comparing the post-reform output figures with their pre-reform levels due to unaccounted private sector and informal trade in the latter period as well as the welfare effects of the reforms, for example the reduction of shortages (Lane, 1992).

${ }^{15}$ Belcerowitz (1995) discusses the importance of these factors in some eastern European countries in transition.
} 
Republic, Poland and Hungary in 1994 also corresponds to the relative shares of the private sector in these countries prior to the reforms.

Moreover, the Czech Republic, Slovak Republic and Hungary are the only countries in the sample that have not experienced triple-digit inflation rates since the initiation of reforms. Not only have the Czech Republic and Hungary had, on average, much lower rates of inflation than the rest of the sample since 1989, but they have also had the highest degree of CBI in the sample (Tables 2 and $3^{16}$ ). It thus appears that the initial economic conditions and market structures may be closely associated with the success of market reforms. CB reforms can be viewed as a part of the wide ranging economic reforms induced by the prevailing economic conditions, institutions and incentive structures. There may therefore be a simultaneous relationship between CBI and macroeconomic performance.

\subsection{Correlation analysis}

To analyse the impact of $\mathrm{CB}$ reforms on economic performance, we distinguish between two periods over which we average the time-series data in every country. First, we use the data that cover 1 year before and 1 year after the enactment of the most recent CB laws (also including the year of the enactment, if close to the mid-year) in order to account for the initial economic status of each country. Second, we use the period covering the 3 years after the enactment dates of the most recent CB laws in each country. Hence, the analysis employed here is an event analysis, rather than a panel, or cross-sectional study.

Due to the small number of data points, we simply perform rank correlation tests to analyse the association between macroeconomic performance indicators and CBI and FMD in the sample countries. Tables 6 and 7 report the rank correlations, with robust errors, corresponding to the first and second sample periods, respectively. ${ }^{17}$ Table 6 shows that both CBI and FMD (measured by M2GDP and the interest spread: 1-d) are significantly correlated with inflation with the expected signs. ${ }^{18}$ The positive correlation between both M2GDP and TDGDP and real growth is possibly due to the positive impact of both price stability and financial sector discipline on investment and growth. Among the FMD indicators, only M2GDP is significantly correlated with deficits, where the positive correlation indicates that M2GDP may in fact not be a good measure of financial deepening, at least in the transition context.

When we use averages of data over the periods that cover 3 years after the enactment of the most recent CB laws, all measures of CBI and FMD, with the exception of real interest rates are found significant at 1 and 5\% levels (the latter only for CRprvt). In addition, their coefficients, reported in Table 7, are all higher as compared to the first sample reported in Table 6. These findings suggest that CBI may have a positive impact on lowering inflation, notwithstanding the possible impact of favourable initial economic or structural conditions

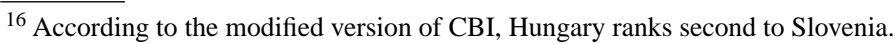

${ }^{17}$ We use rank correlations to abstract from possible scaling problems, especially given the short time-series.

${ }^{18}$ Result of the same nature obtains for the legal CBI index of CWN (1992), i.e. before modification, with the addition, however, of a significant positive correlation of that index with real GDP growth.
} 
Table 6

Rank correlations between CBI, FMD and economic variables ${ }^{\mathrm{a}}$

\begin{tabular}{|c|c|c|c|c|c|c|}
\hline \multirow[t]{2}{*}{ Dependent variables } & \multirow[t]{2}{*}{ CBI } & \multicolumn{5}{|l|}{ FMD measures } \\
\hline & & CRprvt & M2GDP & $1-d$ & TDGDP & Rint \\
\hline Inflation & $\begin{array}{l}-0.48^{* * *}(-2.62) \\
0.23\end{array}$ & $\begin{array}{l}-0.11(-1.51) \\
0.21\end{array}$ & $\begin{array}{l}-0.74^{* * *}(-3.05) \\
0.54\end{array}$ & $\begin{array}{l}0.64^{* * *}(3.38) \\
0.41\end{array}$ & $\begin{array}{l}-0.46(-1.48) \\
0.15\end{array}$ & $\begin{array}{l}0.54(1.27) \\
0.19\end{array}$ \\
\hline Deficits/GDP & $\begin{array}{l}0.21(0.85) \\
0.05\end{array}$ & $\begin{array}{l}-0.14^{* *}(-2.25) \\
0.39\end{array}$ & $\begin{array}{l}0.52^{* *}(2.24) \\
0.27\end{array}$ & $\begin{array}{l}-0.33(-0.87) \\
0.11\end{array}$ & $\begin{array}{l}-0.36(-0.85) \\
0.10\end{array}$ & $\begin{array}{l}-0.54(-1.40) \\
0.28\end{array}$ \\
\hline Real GDP growth & $\begin{array}{l}0.27(1.02) \\
0.08\end{array}$ & $\begin{array}{l}0.19^{* * *}(3.13) \\
0.64\end{array}$ & $\begin{array}{l}-0.11(-0.36) \\
0.01\end{array}$ & $\begin{array}{l}-0.04(-0.10) \\
0.001\end{array}$ & $\begin{array}{l}0.66^{* *}(2.39) \\
0.44\end{array}$ & $\begin{array}{l}0.36(0.96) \\
0.09\end{array}$ \\
\hline
\end{tabular}

a The values are: rank correlation coefficients; $t$-ratios and coefficients of determination, in that order. Sample: average of a year before and after the enactment of the most recent central bank laws.

** Significant at $5 \%$ confidence level.

${ }^{* * *}$ Significant at $1 \%$ confidence level. 
Table 7

Rank correlations between CBI, FMD and economic variables ${ }^{\mathrm{a}}$

\begin{tabular}{|c|c|c|c|c|c|c|}
\hline \multirow[t]{2}{*}{ Dependent variables } & \multirow[t]{2}{*}{$\mathrm{CBI}$} & \multicolumn{5}{|l|}{ FMD measures } \\
\hline & & CRprvt & M2GDP & $1-d$ & TDGDP & Rint \\
\hline Inflation & $\begin{array}{l}-0.62^{* * *}(-2.69) \\
0.38\end{array}$ & $\begin{array}{c}-0.12^{* *}(-2.30) \\
0.34\end{array}$ & $\begin{array}{l}-0.81^{* * *}(-5.05) \\
0.66\end{array}$ & $\begin{array}{l}0.71^{* * *}(3.31) \\
0.51\end{array}$ & $\begin{array}{l}-0.75^{\text {*** }}(-2.58) \\
0.40\end{array}$ & $\begin{array}{l}0.29(0.75) \\
0.08\end{array}$ \\
\hline Deficits/GDP & $\begin{array}{l}0.12(0.69) \\
0.01\end{array}$ & $\begin{array}{l}-0.19^{* * *}(-4.03) \\
0.70\end{array}$ & $\begin{array}{l}0.17(0.58) \\
0.03\end{array}$ & $\begin{array}{l}-0.14(-0.46) \\
0.02\end{array}$ & $\begin{array}{l}-0.71^{* * *}(-2.51) \\
0.36\end{array}$ & $\begin{array}{l}-0.14(-0.27) \\
0.01\end{array}$ \\
\hline Real GDP growth & $\begin{array}{r}-0.07(-0.21) \\
0.01\end{array}$ & $\begin{array}{l}0.13^{* *}(2.08) \\
0.33\end{array}$ & $\begin{array}{l}0.12(0.36) \\
0.01\end{array}$ & $\begin{array}{c}-0.57^{* *}(-2.32) \\
0.33\end{array}$ & $\begin{array}{l}0.50^{* *}(1.89) \\
0.25\end{array}$ & $\begin{array}{l}0.21(0.84) \\
0.04\end{array}$ \\
\hline
\end{tabular}

a The values are: rank correlation coefficients; $t$-ratios and coefficients of determination, in that order. Sample: average of 3 years following the enactment of the recent central bank laws.

** Significant at 5\% confidence level.

*** Significant at $1 \%$ confidence level. 
on both the creation of relatively more independent CBs and lower levels of inflation. ${ }^{19}$ We also observe that the correlations of both CRprvt and TDGDP with deficits become significantly negative in the post CBI period. The negatively significant correlation between interest spread and growth is also revealed in this sample.

Notwithstanding the difficulties in disentangling the direction of causation between price-stability, good economic performance and institutional reforms, the main findings of this paper thus suggest that both CBI and FMD are positively associated with good economic performance. In particular, they suggest that both CBI and FMD are significantly linked to inflation stabilisation. In addition, the findings suggest that there is a negative relationship between budget deficits and FMD and positive relationship between growth and FMD.

\section{Conclusions}

In view of the fiscal and financial problems inherited from the system of central planning, this study hypothesises that both CBI and FMD are significantly related with macroeconomic performance in transition economies. The measurement of legal CBI based on a comprehensive set of criteria indicates that, in the early 1990s, many eastern European economies in transition have enacted $\mathrm{CB}$ laws that granted the $\mathrm{CBs}$ rather high levels of independence. We, nevertheless, argue that imposing overly strict legal lending limits on the $\mathrm{CB}$ may not be sustainable and, therefore, credible in many transition economies. Given the high social and political costs of transition, setting realistic targets for monetary policies and maintaining transparency, both in lending and in rescue operations, are important for both the credibility of monetary policies and the success of market reforms.

Our empirical inquiry via an event analysis suggests positive association of both CBI and FMD with price stability. In addition, credit to the private sector, in ratio to GDP, and the ratio of time deposit to GDP, as measures of FMD, appear to be significantly associated with budget deficits and real GDP growth in the period that follows the enactment of the recent CB laws. Another measure of FMD, the interest rate spread, is also significantly associated with growth in the period that follows the enactment of the recent $\mathrm{CB}$ laws.

\section{Acknowledgements}

I am grateful to Mancur Olson for his invaluable comments. I also thank the participants of the seminar at Tilburg University. In addition, I benefited greatly from the comments of two anonymous referees. Responsibility for all errors and shortcomings remains mine alone.

\footnotetext{
${ }^{19}$ Regression of inflation on both CBI and FMD, where the interest rate spare used as a measure, improves the R-bar square, whereas other measures of FMD do not yield the same result.
} 


\section{Appendix A}

List of criteria for measuring legal CBI, CWN

\begin{tabular}{|c|c|c|}
\hline & & $\begin{array}{l}\text { Numerical } \\
\operatorname{code}^{\mathrm{a}, \mathrm{b}}\end{array}$ \\
\hline \multicolumn{3}{|l|}{ CEO } \\
\hline Term of office & Over 8 years & 1.00 \\
\hline \multirow[t]{4}{*}{$(0.05)$} & $6-8$ years & 0.75 \\
\hline & 5 years & 0.50 \\
\hline & 4 years & 0.25 \\
\hline & $\begin{array}{l}\text { Under } 4 \text { years or at the } \\
\text { discretion of the } \\
\text { appointer }\end{array}$ & 0.00 \\
\hline Who appoints CEO? & Board of $\mathrm{CB}$ & 1.00 \\
\hline \multirow[t]{4}{*}{$(0.05)$} & $\begin{array}{l}\text { A council of CB board, } \\
\text { executive and } \\
\text { legislative branches }\end{array}$ & 0.75 \\
\hline & The legislature & 0.50 \\
\hline & The executive (council of ministers) & 0.25 \\
\hline & One or two members of executive branch & 0.00 \\
\hline Dismissal of CEO: & No provision & 1.00 \\
\hline \multirow[t]{6}{*}{$(0.05)$} & Only for reasons not related to policy & 0.83 \\
\hline & At the discretion of CB board & 0.67 \\
\hline & At legislature's discretion & 0.50 \\
\hline & Unconditional dismissal possible by legislature & 0.33 \\
\hline & At executive's discretion & 0.17 \\
\hline & Unconditional dismissal possible by executive & 0.00 \\
\hline $\begin{array}{l}\text { May CEO hold } \\
\text { other offices in } \\
\text { the government? }\end{array}$ & No & 1.00 \\
\hline \multirow[t]{2}{*}{$(0.05)$} & Only with permission of the executive branch & 0.50 \\
\hline & No rule against holding another office & 0.00 \\
\hline \multicolumn{3}{|l|}{ Policy formulation } \\
\hline Who formulates? & $\mathrm{CB}$ alone & 1.00 \\
\hline \multirow[t]{3}{*}{$(0.05)$} & CB participates, but has little influence & 0.67 \\
\hline & CB only advises the government & 0.33 \\
\hline & CB has no say & 0.00 \\
\hline \multicolumn{3}{|l|}{$\begin{array}{l}\text { Who says the final word } \\
\text { in resolution of conflict? }\end{array}$} \\
\hline$(0.05)$ & $\begin{array}{l}\mathrm{CB} \text {, on issues defined in the law as } \\
\text { its objectives }\end{array}$ & 1.00 \\
\hline
\end{tabular}


Appendix A (Continued)

Role of CB in

\begin{tabular}{|c|c|c|}
\hline & & $\begin{array}{l}\text { Numerical } \\
\operatorname{code}^{a, b}\end{array}$ \\
\hline & Government, on issues not defined as CB's & 0.80 \\
\hline & $\begin{array}{l}\text { A council of } \mathrm{CB} \text { and executive and } \\
\text { legislative branches }\end{array}$ & 0.60 \\
\hline & The legislature & 0.40 \\
\hline & $\begin{array}{l}\text { The executive, subject to due process and } \\
\text { protests of } \mathrm{CB}\end{array}$ & 0.20 \\
\hline & Unconditional priority of the executive & 0.00 \\
\hline \multirow{3}{*}{$\begin{array}{l}\text { Role of CB in } \\
\text { budgetary process: } \\
(0.05)\end{array}$} & & \\
\hline & $\mathrm{CB}$ is active & 1.00 \\
\hline & $\mathrm{CB}$ has no influence & 0.00 \\
\hline
\end{tabular}

Objectives

Price stability is the only objective and CB

has the final word in case it conflicts with government objectives

Price stability is the only objective $\quad 0.80$

Price stability is one of compatible goals, $\quad 0.60$

such as financial stability

Price stability is one of incompatible goals, $\quad 0.40$

such as full-employment

No objectives stated in the CB charter $\quad 0.20$

Stated objectives do not include price stability $\quad 0.00$

Limitations on lending

to the government

Advances

$(0.15)$

Not permitted

1.00

Permitted, with strict limits (up to $15 \%$ of

0.67

government revenue)

Permitted, with loose limits (over $15 \%$ of $\quad 0.33$

government revenue)

No legal limits on lending $\quad 0.00$

Securitised lending

Not permitted

1.00

$(0.10)$

Permitted, with strict limits (up to $15 \%$ of

0.67

government revenue)

Permitted, with loose limits (over $15 \%$ of $\quad 0.33$

government revenue)

No legal limits on lending $\quad 0.00$ 
Appendix A (Continued)

\begin{tabular}{|c|c|c|}
\hline & & $\begin{array}{l}\text { Numerical } \\
\operatorname{code}^{\mathrm{a}, \mathrm{b}}\end{array}$ \\
\hline Terms of lending & Controlled by the $\mathrm{CB}$ & 1.00 \\
\hline \multirow[t]{3}{*}{$(0.10)$} & Specified by the CB charter & 0.67 \\
\hline & Agreed between the $\mathrm{CB}$ and the executive & 0.33 \\
\hline & Decided by the executive alone & 0.00 \\
\hline Potential borrowers & Only the central government & 1.00 \\
\hline \multirow[t]{3}{*}{$(0.05)$} & All levels of government (local, state) & 0.67 \\
\hline & Those mentioned above and state enterprises & 0.33 \\
\hline & Public and private sector & 0.00 \\
\hline Limits on lending & In currency amounts & 1.00 \\
\hline \multirow[t]{3}{*}{ (0.025) } & In shares of CB demand liabilities or capital & 0.67 \\
\hline & In shares of government revenues & 0.33 \\
\hline & In shares of government expenditures & 0.00 \\
\hline Maturity of loans & Within 6 months & 1.00 \\
\hline \multirow[t]{3}{*}{$(0.025)$} & Within 1 year & 0.67 \\
\hline & More than 1 year & 0.33 \\
\hline & No mention of maturity in the law & 0.00 \\
\hline Interest rates on loans & Above minimum rates & 1.00 \\
\hline \multirow[t]{4}{*}{$(0.025)$} & At market rates & 0.75 \\
\hline & Below maximum rates & 0.50 \\
\hline & Interest rate is not mentioned & 0.25 \\
\hline & No interest on loans to the government & 0.00 \\
\hline \multirow{3}{*}{$\begin{array}{l}\text { Is CB prohibited } \\
\text { from buying and selling } \\
\text { government securities } \\
\text { in the primary market? } \\
(0.025)\end{array}$} & & \\
\hline & Yes & 1.00 \\
\hline & No & 0.00 \\
\hline
\end{tabular}

\footnotetext{
a Notes: (i) the ranking under each criteria indicates the degree of independence of central banks, the higher the numerical code, the more independent is the central bank; (ii) in case the $\mathrm{CB}$ law does not have a separate provision on the resolution of conflict, the codes are based on the general impression from other provisions in the law.

b Sources: Various Central Bank Laws, 2001, Aufricht (1967); Bank for International Settlements (1963); Effros (1982), and the IMF's computerised files on CB laws.
} 


\section{Appendix B}

Codings of the Criteria for CBI

\begin{tabular}{|c|c|c|c|c|c|c|c|c|c|}
\hline Criteria $^{a}$ & & Albania & Bulgaria & $\begin{array}{l}\text { Czech } \\
\text { Republic }\end{array}$ & Hungary & Poland & Romania & $\begin{array}{l}\text { Slovak } \\
\text { Republic }\end{array}$ & Slovenia \\
\hline \multirow[t]{4}{*}{1} & Term of office & 0.75 & 0.5 & 0.75 & 0.75 & 0.75 & 0.0 & 0.75 & 0.75 \\
\hline & Appointment & 0.75 & 0.5 & 0.5 & 0.5 & 0.5 & 0.5 & 0.5 & 0.5 \\
\hline & Dismissal & 0.83 & 0.83 & 0.83 & 0.83 & 0.83 & 0.33 & 0.67 & 1.0 \\
\hline & Other office & 0.5 & 1.0 & 1.0 & 1.0 & 1.0 & 1.0 & 1.0 & 1.0 \\
\hline \multirow[t]{3}{*}{2} & Monetary policy & 0.67 & 0.67 & 1.0 & 0.67 & 0.33 & 0.67 & 1.0 & 1.0 \\
\hline & Conflict resolution & 0.2 & NA & 1.0 & 1.0 & 0.6 & 0.4 & 1.0 & 0.4 \\
\hline & Budgetary advise & $N A^{b}$ & NA & $\mathrm{NA}$ & 1.0 & 1.0 & 0.0 & 0.0 & NA \\
\hline 3 & Objectives(3) & 0.6 & 0.6 & 0.8 & 0.6 & 0.6 & 0.4 & 0.6 & 0.8 \\
\hline \multirow[t]{8}{*}{4} & Limit on advances & 0.33 & 0.67 & 0.67 & 0.67 & 0.0 & 0.33 & NA & 0.67 \\
\hline & Securitised lending & 0.67 & 0.0 & 0.67 & NA & 0.67 & 0.0 & 0.67 & 0.0 \\
\hline & Terms of lending & 0.33 & 0.33 & 0.67 & 0.33 & 0.33 & 0.33 & 0.67 & 1.0 \\
\hline & Width of borrowers & NA & NA & NA & 1.0 & 0.33 & NA & 0.0 & NA \\
\hline & Type of limits & 0.33 & 0.33 & 0.33 & 0.33 & 0.0 & 0.0 & 0.33 & 0.0 \\
\hline & Maturity of lending & 1.0 & 1.0 & 1.0 & 0.33 & 0.0 & 0.0 & 1.0 & 0.67 \\
\hline & Lending interest & 0.75 & 0.25 & 0.25 & 0.75 & 0.25 & 0.25 & NA & 0.25 \\
\hline & Primary market & 0.0 & 1.0 & 0.0 & 0.0 & 0.0 & 0.0 & 0.0 & 0.0 \\
\hline \multirow[t]{2}{*}{5} & Bank budget & 0.5 & 1.0 & 1.0 & 1.0 & 0.5 & NA & 1.0 & NA \\
\hline & CEO salaries & 0.5 & 1.0 & 1.0 & 1.0 & 1.0 & NA & 1.0 & NA \\
\hline 6 & Supervision & 0.0 & 0.33 & 1.0 & 0.67 & 0.0 & 0.0 & 1.0 & 1.0 \\
\hline 7 & Emergency credit & 0.0 & 1.0 & 0.0 & 1.0 & 0.0 & 1.0 & 0.0 & 0.0 \\
\hline
\end{tabular}

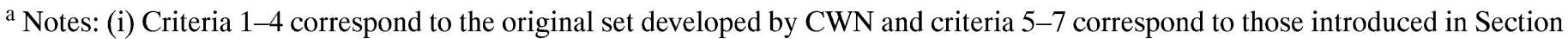
2 of this paper; (ii) larger numbers indicate higher independence.

bA: not applicable. 


\section{References}

Alesina, A., Summers, L., 1993. Central bank independence and macroeconomic performance: some comparative evidence. J. Money, Credit Bank. 25, 151-162.

Aufricht, Hans, 1967. Central Banking legislation. Vol II, Europe, Washington D.C.: IMF.

Barro, R., Gordon, D.B., 1983. Rules versus discretion and reputation in a model of monetary policy. J. Monetary Econ. 12, 101-122.

Belcerowitz, L., 1995, Socialism, Capitalism and Transformation. Central European University Press, Budapest.

Clague, C., Keefer, P., Knack, S., Olson, M., 1995. Contract-intensive money: contract enforcement, property rights and economic performance, mimeo IRIS. University of Maryland, College Park, MD.

Cukierman, A., Meltzer, A., 1989. Positive theory of government debt and deficits in a neo-Ricardian framework. Am. Econ. Rev. 79, 713-732.

Cukierman, A., 1992. Central bank strategy, credibility and independence: theory and evidence. MIT Press, Cambridge, MA.

Cukierman, A., Webb, S., Neyapti, B., 1992. Measuring the independence of central banks and its effects on policy outcomes. World Bank Econ. Rev. 6, 353-398.

Cukierman, A., Miller, G., Neyapti, B., 2002. Central bank independence, liberalization and inflation in transition economies-an international perspective. J. Monetary Econ., in press.

Debelle, G., Fischer, S., 1994. How independent should a central bank be? MIT Press, Cambridge, MA.

European Bank for Reconstruction and Development, 1999. Transition Update. London, UK.

Goodhart, C.A.E., 1995. The Central Bank and the Financial System. MIT Press, Cambridge, MA.

Goodman, J.B., 1991. The politics of central bank independence, J. Compar. Pol. 23.

Grilli, V., Masciandaro, D., Tabellini, G., 1991. Political and Monetary Institutions and Financial Policies in Industrial Economies: Economic Policy: A European Forum, 6, 342-392.

Heller, R.H., 1991. Prudential supervision and monetary policy. In: Downes, P., Zadeh, R.V. (Eds.), The evolving role of central banks. International Monetary Fund, Washington, DC.

Keesings Records of World Events, various issues.

Lane, T.D., 1992. Inflation stabilization and economic transformation in Poland: the first year. Carnegie-Rochester Conf. Ser. Public Policy 36, 105-156.

Loungani, P., Sheets, N., 1997. Central bank independence, inflation and growth in transition economies. J. Money, Credit Bank. 29, 181-192.

Maxfield, S., 1994. Financial incentives and central bank authority in industrializing nations. World Pol. 46, 556-588.

Maxfield, S., 1997. Gatekeepers of Growth. Princeton University Press, Princeton, NJ.

McKinnon, R., 1992. Taxation, money and credit in a liberalizing socialist economy. In: Clague, C., Rausser, G.D. (Eds.), The Emergence of Market Economies in Europe. Blackwell Scientific Publications, Cambridge, MA, pp. 109-128.

Neyapti, B., 1997. Budget deficits and inflation: an analysis in light of the roles of central bank independence and financial market development, unpublished Ph.D. Thesis. Department of Economics, University of Maryland, College Park, MD.

Olson, M., 1995. Why the transition from communism is so difficult. Eastern Econ. J. 21, 437-462.

Posen, A., 1994. Central bank independence and disinflationary credibility: a missing link, Brookings Discussion Papers in International Economics, Vol. 109. Brookings Institution, Washington, DC, pp. 1-48.

Roe, A., 1992. Financial sector reform in transitional socialist economies, Economic Development Institute Seminar Report 29. The World Bank, Washington, DC.

Siklos, P., 1993. Central bank independence in central Europe: a preliminary investigation. Wilfrid Laurier University, Waterloo, Ont., Canada.

Sundararajan, A., 1990. Financial sector reform and central banking in centrally planned economies, IMF Working Paper 120. International Monetary Fund, Washington, DC.

Thorne, A., 1993. Eastern Europe's experience with banking reform: is there a role for banks in the transition? J. Bank. Finance 17, 959-1000.

Various Central Bank Laws. 